\title{
REVIEW
}

\section{Catch and Release: A Review of the Mermaid of Black Conch by Monique Roffey}

\author{
Alison Glassie \\ University of Virginia, US \\ alison.glassie@gmail.com
}

Review of Monique Roffey, The Mermaid of Black Conch: A Love Story. Peepal Tree Press, 2020. 188 pages.

Keywords: Monique Roffey; ocean; mermaids; queer; love story

In Monique Roffey's latest novel, the Costa Award-winning The Mermaid of Black Conch: A Love Story, a thousand-year old Taino mermaid named Aycayia resurfaces to indict the logics of possession and extraction that have shaped the Caribbean since colonial contact. Having swum afoul of a sportfishing derby off the rural island of Black Conch in 1976, Aycayia is hooked-quite literally-by "white men from Florida [who] came to fish for marlin and instead pulled a mermaid out of the sea" (7). The ensuing novel, which follows its eponymous mermaid's rescue and slow, temporary transformation from "barnacled, seaweed-clotted mermaid" to womanhood, explores Aycayia's awakening sexuality and foregrounds the transgressive-perhaps even queer-nature of love itself (7). Subtitled "a love story", The Mermaid of Black Conch is actually a story about love. This distinction is less semantic than it might initially seem. As the novel juxtaposes relationships founded upon power, possession and extraction with the genuine loves and frustrations-erotic and otherwise-of the characters who participate in Aycayia's rescue and wonder aloud about the curse that binds her to the sea, it suggests, following Angelique Nixon and Antonio Benitez-Rojo, that in queerness of gender, sexuality, and literary form, one finds a Caribbeanness as fluid and expansive as the sea itself.'

The author of six novels, four of which are set in Trinidad and the Caribbean, Roffey is a Senior Lecturer on the MA/MFA in Creative Writing at Manchester Metropolitan University, and a tutor at the Norwich Writers Centre. Her work has consistently been recognized for major awards in British and Caribbean fiction and in environmental literature. The Mermaid of Black Conch, for instance, has won the Costa Book of the Year Award and was shortlisted for the Goldsmiths Prize and longlisted for the Rathbones/Folio Award. House of Ashes (2014) was, in 2015, shortlisted for the Costa Novel Award and longlisted for the OCM Bocas Award. 2012's Archipelago won the OCM Bocas Award in 2013 and was shortlisted for the Orion Award in 2014. The White Woman on the Green Bicycle (2009), her second novel, was shortlisted for the Orange Prize (2010), and the Encore Award (2011). Roffey has also turned her hand to literary erotica (The Tryst, 2017) and sexual memoir (With the Kisses of His Mouth 2012). With The Mermaid of Black Conch, Roffey fuses her interests in environmentalism and erotica. Her deft treatment of sexual exploration, violence, and consent participates in a growing, multilingual tradition of Caribbean sea fiction which foregrounds the maritime knowledge of queer or sea creaturely characters, and in which African and Indigenous cosmologies, in tandem with elements of the marine environment, queer the novel form. ${ }^{2}$

\footnotetext{
${ }^{1}$ I am indebted here to Angelique V. Nixon's “Troubling Queer Caribbeanness: Embodiment, Gender, and Sexuality in Nadia Huggins' Visual Art (Caribbean Queer Visualities), and also to Antonio Benitez-Rojo, who, in The Repeating Island, theorizes a gendered, fundamentally "aquatic" Caribbean, "...the natural and indispensable realm of marine currents, of waves, of folds and double-folds, of fluidity and sinuosity," that resists "the cycles of clock and calendar" (11).

2 Other examples of the genre include Lawrence Scott's Witchbroom (1992), Nalo Hopkinson's New Moon's Arms, and Rita Indiana's La Mucama de Omicunlé(2015). For more, see Alison Glassie. "Into the Anemone: Ocean, Form, and the Anthropocene in Tentacle." sx salon, no. 34, 2020, smallaxe.net/sxsalon/discussions/anemone.
} 
Largely written in Creole English, The Mermaid of Black Conch swims between temporalities, narrative strains, and modes including local color and magical realism. Like Lawrence Scott's Witchbroom (1992) and Rita Indiana's La Mucama de Omicunlé(2015), it revels in waterlogged metatextuality, and in sea-creaturely literary and corporeal forms. A 2015 journal, written by a local fisherman called David Baptiste, recounts the events surrounding Aycayia's stay in Black Conch forty years prior. As he documents the messy return to human form taking place in his bathtub-the mermaid shedding her tail in rotting chunks as seawater and tiny crabs spill from her ears-David's wry, tender attention shifts to arousal and then, to love. Meanwhile, Roffey's omniscient narration drives the plot forward, fleshing out the island of Black Conch (a fictionalized Tobago) and introduces a cast of supporting characters including landowner Miss Arcadia Rain-a "white woman with a Creole song in her mouth" much like Roffey herself. The novel's haunting focal point, the mermaid's story, told in verse she has written with a pencil and paper salvaged from a shipwreck, "opens a door in the universe," figuring Derek Walcott's famous theory of the Caribbean Sea as history as, instead, a "herstory" that extends centuries before caravels appeared on the Atlantic horizon (82).

Consigned to the deep by jealous wives and goddesses, Aycayia "sweet voice" and her companion Guanayoa, an old woman who told "uncomfortable truths" are, respectively, hybridized with the blue marlin (Makaira nigricans) beloved of sport fishermen and the leatherback sea turtle (Dermochelys coriacea) that has persisted in the oceans for nearly 100-million-years. ${ }^{3}$ Joined by intergenerational female friendship and by an ongoing history of extraction that sees leatherbacks perish as bycatch in the marlin fishery, Aycayia and Guanayoa-fast, pelagic predators and ancient, migratory marine reptiles-register deep evolutionary history and revise the tradition of figuring male master mariners as sea creatures that began in novels by Rudyard Kipling and Jack London. ${ }^{4}$ In this sense, The Mermaid of Black Conch continues a project Roffey began in Archipelago (2012) - a reimagination of the sea fiction genre that critiques, even queers, the masculinities associated with traditional protagonists of the sea. ${ }^{5}$ With Archipelago, Roffey offers a feminist revision of the nautical adventure novel: critiquing her protagonist's inattentive reading of Moby-Dick(1851) and introducing, in Captain Phoebe Wolf, a dolphin-like rejoinder to London's brutal, hypermasculine Wolf Larsen (The Sea Wolf, 1904). In The Mermaid of Black Conch, she trains her sights on Papa Hemingway.

An admitted riff on Hemingway's posthumous Islands in the Stream (1970), the harrowing fight scene that opens The Mermaid of Black Conch critiques sportfish tourism and the neocolonial logics whereby American fishermen consume the Caribbean: "snapp[ing] plenty photographs of pirogues, of sunsets, of rasta men liming, one leg cocked up against a wall; they fish[ed], fuck[ed] the local women, smok[ed] the local weed, drank the local babash" (43). ${ }^{6}$ Over two chapters, named respectively for the pirogue Simplicity (a canoe-like vessel derived from indigenous and African dugouts) and the souped-up sportfisher Dauntless, the scene juxtaposes local coexistence with the Caribbean Sea with neocolonial consumption. When Aycayia surfaces to listen to David's hymns, he looks askance at his spliff and offers "soft soft and gentlemanlike" words to the flattening water (9). By contrast, banker Thomas Clayson steams in from Miami in order to "make a man" of his sensitive, intellectual son, who promptly hooks what seems to be a massive female blue marlin. "Imagine," the elder Clayson thinks to himself, "having a son capable of such a conquest" (21).

In the tense, sexually-charged sequence that follows, Aycayia-woman, marlin, and marine ecosystem in and of herself-breaches. Her muscular body, spiky dorsal fin, and "dreadlocks of a man o'war" streaming with stinging tentacles and fire coral-at once fearsome and alluring-have an immediate, magnetic effect on the Claysons and their local crew (28). "I want you," one fisherman whispers, "repulsed" (30). Clayson's conquest indicts the would-be conquistador; Aycayia is gaffed and wrestled ashore: strung upside-down on the jetty between two marlin "lynched by their tails" (32). Pairing this image of racial violence with a graphic description of the Trumpian elder Clayson's sexual assault on the immobilized indigenous mermaid she describes as "reverse crucified", Roffey renders a disturbing turn on the classic trophy-fishing photograph, illustrating that possessive violence transgresses race, species, and gender (35). In doing so, she extends to the present

\footnotetext{
${ }^{3}$ Callum Roberts. The Unnatural History of the Sea. 2007, p. 285. The very temporality of the novel-from April to October, tracks with the leatherback migration from the Greater Antilles to Trinidad and Tobago.

${ }^{4}$ Cristina Bacchilega and Marie Alohalani Brown. The Penguin Book of Mermaids. 2019, pp. xxii; Bert Bender. Sea Brothers: The Tradition of American Sea Fiction from Moby-Dick to the Present. U of Penn P, 1990.

${ }^{5}$ For a more substantive version of this argument, see Alison Glassie. "Archipelago's Voyage: Climate and Seamanship in Monique Roffey's Contemporary Sea Novel." Interdisciplinary Studies in Literature and the Environment, vol. 26, no. 4, 2019, https://doi. org/10.1093/isle/isz027.

${ }^{6}$ According to Roffey's author's note, "the catch scene owes partial homage to Hemingway's Islands in the Stream" (188).
} 
a longue-durée colonial history in which the decimation of marine megafauna like sea turtles, monk seals, and grouper-like indigenous genocide-began soon after the "murder admiral" Columbus stepped ashore. ${ }^{7}$

David's rescue of Aycayia, an act of resistance against Clayson's conquest, initiates the mermaid's marronage and by extension The Mermaid of Black Conch's intervention in sea fiction and the queer Caribbean. By centering Aycayia's story, Roffey expands the concern with Afro-Caribbean spirituality that Omise'ke Natasha Tinsley observes in queer Caribbean fiction to include Taino myth and cosmology. ${ }^{8}$ Moreover, by jettisoning the European "colonial times" mermaid that appears in Clayson's fish tales and in her novel's epigraph-a quotation from one of Columbus' logbooks that references a manatee-Roffey may also be making an effort to shed the 2014 controversy that led to accusations that she herself is a "latter day Columbus." ${ }^{9}$ Although its three central couples are, more or less, heterosexual, the interspecies dimension of David's romance with Aycayia, like the younger Clayson's bisexuality, "challenge Caribbean traditions of heteropatriarchy and binary gender" (qtd. in Nixon 104) and refute the masculinist game fish conquistador mentality often associated with Hemingway's works. Ultimately, The Mermaid of Black Conch anchors its argument for an expansive, fluid, queer Caribbean in the mouths of its supporting characters, who wonder aloud about the curse that transformed Aycayia into a mermaid and bound her to the sea. Does the curse win, these characters-and by extension the very novel-ask? Certainly, The Mermaid of Black Conch's Costa win, which Roffey describes to The Irish Times' Martin Doyle as "a vote for so many things: Caribbean literature, experimental form, magical realism, independent presses, and of course, mermaids"-might be read as a testament of love to the contrary.

\section{Competing Interests}

The author has no competing interests to declare.

\footnotetext{
7 See, for instance, W. Jeffrey Bolster. The Mortal Sea. Belknap, 2014; Lisabeth Paravisini-Gebert. "Extinctions: Chronicles of Vanishing Fauna in the Colonial and Postcolonial Caribbean." Edited by Greg Garrard, The Oxford Handbook of Ecocriticism. Oxford UP, 2007, and Callum Roberts. The Unnatural History of the Sea. Island Press, 2007.

${ }^{8}$ See Omise'eke Natasha Tinsley. Ezili's Mirrors: Imaging Black Queer Genders. Duke UP, 2018, loc. 134.

9 St. Lucian poet Vladimir Lucien lodged this critique in a July, 2014 Caribbean Lit Time blog post entitled "Monique Roffey's Discovery of Caribbean Literature." caribbeanlitlime.wordpress.com/2014/07/23/monique-roffeys-discovery-of-caribbean-literature/.
} 
How to cite this article: Glassie, A 2021 Catch and Release: A Review of The Mermaid of Black Conch by Monique Roffey. Anthurium, 17(1): 7, 1-4. DOI: https://doi.org/10.33596/anth.448

Published: 01 September 2021

Copyright: (c) 2021 The Author(s). This is an open-access article distributed under the terms of the Creative Commons Attribution 4.0 International License (CC-BY 4.0), which permits unrestricted use, distribution, and reproduction in any medium, provided the original author and source are credited. See http://creativecommons.org/licenses/by/4.0/. 